\title{
Fluctuating asymmetry and allozyme variability in an isolated springbok Antidorcas marsupialis population from the Chelmsford Nature Reserve
}

\author{
Paul J. GROBLER, Peter J. TAYLOR,
} Malan D. PRETORIUS and Corne P. ANDERSON

\begin{abstract}
Grobler P. J., Taylor P. J., Pretorius M. D. and Anderson C. P. 1999. Fluctuating asymmetry and allozyme variability in an isolated springbok Antidorcas marsupialis population from the Chelmsford Nature Reserve. Acta Theriologica 44: 183-193.
\end{abstract}

Allozyme variability and fluctuating asymmetry (FA) in skull morphology were used to test the hypothesis of inbreeding in an isolated springbok Antidorcas marsupialis (Zimmermann, 1780) population from the Chelmsford Nature Reserve, South Africa. Of 39 loci studied in a sample of 30 animals, five displayed allelic polymorphism. Average heterozygosity of $1.8 \%$ was not appreciably lower than a value of $2 \%$ calculated for 49 animals from a control group from Benfontein Game Farm in the Northern Cape Province, South Africa. Proportion of polymorphic loci and average number of alleles per locus were identical in both populations (10.3\% and 1.1). Morphological analysis contradicted the prediction of increased fluctuating asymmetry due to the likelihood of inbreeding in a small, isolated population, with FA almost always higher in the control compared to Chelmsford. Chelmsford animals were however smaller than control animals for seven out of 9 cranial and horn variables analysed (significantly so in four cases), hich could conceivably be explained by environmental influences. It is concluded that loss of genetic diversity is not a problem in the Chelmsford springbok population, although this does not negate the possibility that physical deformities occurring in the population may indeed be genetically induced.

Department of Zoology and Biology, University of the North, P/Bag X1106, Sovenga, 0727, South Africa (PJG, MDP); Durban Natural Science Museum, P.O. Box 4085, Durban, 4000, South Africa (PJT); McGregor Museum, P.O. Box 316, Kimberley, 8300, South Africa (CPA)

Key words: Antidorcas marsupialis, heterozygosity, fluctuating asymmetry

\section{Introduction}

A population of less than 50 springbok Antidorcas marsupialis (Zimmermann, 1780 ) was introduced into the Chelmsford Nature Reserve $\left(27^{\circ} 41^{\prime} \mathrm{S}, 2^{\circ} 53^{\prime} \mathrm{E}\right)$, KwaZulu-Natal, South Africa, during the 1970s. By 1996, the descendants numbered 490 and displayed a high percentage of horn deformities amongst females (Fig. 1) as well as perceived decreased reproductive performance. Since no additional animals were added since the original introduction, it was speculated that the abnormalities in Chelmsford may be indicative of inbreeding. Genetically 
determined alternative biochemical or physiological phenotypes may strongly affect fitness components (Watt 1985). Bigalke and Van Hensbergen (1992) reported abnormal head coloration and reduced body size in an isolated population of blesbok (Damaliscus dorcas phillipsi) showing marked genetic homogeneity. However, reduced body size was attributed to mineral deficiency rather than inbreeding depression. A large number of investigators have documented a relationship between levels of heterozygosity and phenotypic expression (Scribner et al. 1989, Borkowska and Ratkiewicz 1996). Bigalke et al. (1993) mentioned the widespread belief that managed springbok farm herds have suffered size deterioration due to inbreeding and selection of large animals by hunters. The history of the Chelmsford springbok population contains several factors which may enhance genetically based phenotypic degeneration, including expansion from a smaller founder population, reproductive isolation and relaxed selection in the absence of predation. The first objective of the current study was therefore to determine the level of heterozygosity in the Chelmsford springbok population, and compare this to the genetic diversity in a control population. For the latter we studied animals from Benfontein Game Farm ( $\left.28^{\circ} 52^{\prime} \mathrm{S}, 24^{\circ} 48^{\prime} \mathrm{E}\right)$, owned by De Beers Consolidated, near Kimberley in the Northern Cape. Strictly free-ranging springbok populations are scarce (Robinson et al. 1978), but the Benfontein population is typical of the large commercially used herds descendant from wild stock prior to fencing, probably early this century. The size of this particular herd has fluctuated between 2000 and 5000 animals but have never dropped below the first figure.

It has been widely suggested that the measurement of fluctuating asymmetry, or random deviations from bilateral symmetry, provides an index of developmental stability (Palmer and Strobeck 1986, Patterson and Patton 1990). Among other effects such as a high rate of genetic abnormalities, reduced genetic heterozygosity and decreased body size, inbreeding depression may be accompanied by an increase in the degree of fluctuating asymmetry (Soulé 1978, Lacy 1992, Lacy and Horner 1996). A second objective of the current study was thus to compare fluctuating asymmetry and size of craniometric variables between the Chelmsford population and the control population in order to quantify the perceived phenotypic effects and indirectly test the hypothesis of inbreeding in the population.

An association between genetic heterozygosity and morphological attributes (including body and antler size, as well as the degree of asymmetry) was reported by Smith et al. (1983) and Scribner et al. (1989) in white-tailed deer but was not confirmed by results obtained by Hartl et al. (1991) in red deer. A significant negative correlation between heterozygosity and fluctuating asymmetry in morphological characters has been empirically demonstrated in some studies but not in others (see reviews by, inter alia, Palmer and Strobeck 1986, Lacy and Horner 1996). Rather than postulating a causal relationship between genetic heterozygosity and developmental stability, as measured by fluctuating asymmetry, Lacy and Horner (1996) demonstrated in captive Rattus villosissimus that deliberate inbreeding independently led to depressed allozyme heterozygosity and increased 
levels of fluctuating asymmetry (ie developmental instability). In so far as the present study includes data for both genetic heterozygosity and morphological attributes (both cranial size and fluctuating asymmetry) in small and large populations, it should provide further insight into the complex relationship between genetic heterozygosity and phenotypic expression, and the conservation implications of this relationship.

\section{Material and methods}

Tissue samples (blood, liver, kidney and skeletal muscle) and skulls (for morphometric assessment) were collected from 30 Chelmsford springbok ( 22 females and 8 males) during May 1996. To provide an indication of expected genetic diversity in springbok, 49 animals from the large commercially utilised springbok herd on Benfontein, De Beers Consolidated, were also sampled. Genetic diversity and divergence were determined using allozyme techniques. Routine methods (ie Harris and Hopkinson 1976, Murphy et al. 1990) with starch gels and 7-8 V per $\mathrm{cm}$ gel were used to facilitate migration and separation of gene products, and for staining of allozymes. The following 39 presumed protein encoding loci were screened: adenylate kinase (E.C. 2.7.4.3, Ak-1, Ak-2); alcohol dehydrogenase (E.C. 1.1.1.1, Adh-1); creatine kinase (E.C. 2.7.3.2, Ck-1, Ck-2); esterase (E.C. 3.1.1.1, Est-1); glucose-phosphate-isomerase (E.C. 5.3.1.9, Gpi-1); glyceraldehyde-phosphate dehydrogenase (E.C. 1.2.1.12, Gap-1, Gap-2); glycerol-3-phosphate dehydrogenase (E.C. 1.1.1.8, Gpd-1); glucose dehydrogenase (E.C. 1.1.1.47, Gld-1, Gld-2); hexokinase (E.C. 2.7.1.1, Hk-1); isocitrate dehydrogenase (E.C. 1.1.1.42, Idh-1, $I d h-2$ ); lactate dehydrogenase (E.C. 1.1.1.27, $L d h-1, L d h-2$ ); malate dehydrogenase (E.C. 1.1.1.37, $M d h-1, M d h-2)$; malic enzyme (E.C. 1.1.1.40, Me-1); mannose-phosphate isomerase (E.C. 5.3.1.8, Mpi-1, Mpi-2); nonspecific proteins (Prot-1,2,3); nucleoside phosphorylase (E.C. 2.4.2.1, $N p$-1); peptidase (E.C. 3.4.--, Pep-1,2,3,4,5,6); phosphoglucomutase (E.C. 2.7.5.1, Pgm-1, Pgm-2); 6-phosphogluconate dehydrogenase (E.C. 1.1.1.44, Pgd-1, Pgd-2); sorbitol dehydrogenase (E.C. 1.1.1.14, Sdh-1) and superoxide dismutase (E.C. 1.15.1.1, Sod-1, Sod-2). Genetic diversity in each population was quantified using average heterozygosity ( $H$ : Nei 1975), proportion of polymorphic loci $(P)$ and average number of alleles per locus $(A)$; and compared using the fixation index $\left(F_{S T}\right)$ of Wright (1965). We also determined significance of allelic frequency differences between populations and of deviations from expected Hardy-Weinberg proportions of genotypes. Genetic distance $(D)$ was calculated using the widely appliec coefficient of Nei (1972), to facilitate comparison with other published results.

Morphological analysis was based on sub-samples of the animals used for genetic analysis. Seven cranial and two horn measurements were taken on 20 adult female springbok from Chelmsford (measured by PJT), as well as from a sample of 38 adult females from the Benfontein population (measured by PCA). Although measurement error was not statistically tested, this was minimised by choosirg final measurements (from an initial sample of 17 taken on all skulls) which were unambiguous and repeatable. Analysis was restricted to adults and females so as to minimise the effects of morphological variation due to sex and age. Springbok show pronounced sexual dimporhism, with males larger than females, particularly in horn measurements (Rautenbach 1971, Skinner and Smithers 1990). Using calipers with an accuracy of 0.05 or 0.001 , the following cranial measurements were taken on the left and right sides of the skull (see also De Blase and Martin 1981, Patterson and Patton 1990, Vrba et al. 1994):

1. Mandible length (MANDL) - from anterior surface of alveolus of first lower incisor to posterior surface of coronoid process,

2. Condyle-premaxilla length (CONDPL) - from anterior surface of premaxilla to posterior surface of occipital condyle,

3. Maximum length of premaxilla (MAIL) - from anterior surface of premaxilla to premaxilla-nasal suture

4. Distance from maxillary foramen to closest point on inner rim of orbit (MAXORB),

5. Maximum diameter of orbit (ORBIT), 
6. Maximum diameter of auditory bulla (BULLAW) - measured at right angles to skull axis,

7. Occipital condyle width (OCCONW) - measured in a horizontal line from contact between condyle and dorsal edge of foramen magnum, outwards.

Using a tape measure, the following horn measurements were taken on the left and right horns (from 19th edition of Rowland Ward):

8. Horn length - measured on the front surface of the horn from the lowest edge of the base to the tip (HORNL),

9. Circumference of the base of the horn at right angles to the axis of horn, (HORNCIR).

All skulls were assigned to relative age classes according to a chart adapted from Rautenbach (1971) by one of us (PCA). By relative class "4" (9-16 months), fully erupted and permament teeth are present. Only animals of class " 4 " and upwards were considered to be adult, and therefore considered for further analysis. Age classes varied from " 4 " to " 9 " in Benfontein (mean of 6.1 ), and from " 5 " to "9" in Chelmsford (mean of 6.8).

Four standard indices suggested by Palmer and Strobeck (1986) were used to examine and compare the extent of fluctuating asymmetry (FA) in the two populations, corresponding with their indices 1 [mean absolute deviation (MAB)], 3 (MAB scaled for size), 4 [variance of signed asymmetries (VSS)] and 7 (VSS scaled for size).

\section{Results and discussion}

\section{Allozyme divergence}

Polymorphic loci, allelic designations (reflecting relative mobilities), allelic frequencies and genetic variability values in the Chelmsford and Benfontein springbok populations are listed in Table 1. Comparison of genetic diversity levels reveal little if any real difference between the Chelmsford and control populations. Proportion of polymorphic loci and average number of alleles per locus are identical $(10.3 \%$ and 1.1$)$ in both groups, with only a small difference between average heterozygosity values $(1.8$ and $2 \%)$. Significant differences $(p<0.038)$ between allelic frequencies of the two populations was observed in only one (Mpi-2) out of five polymorphic loci. Significant deviations from expected Hardy-Weinberg proportions of genotypes occurred in three loci in the isolated Chelmsford population (Prot-2, $p<0.036$; Pgm-2, $p<0.009$ and Np-1, $p<0.036$ ), with two significant deviations of genotypes in the control group (Pgm-2, $p<0.011$ and $N p-1, p<$ 0.011 ). The $F_{S T}$ value calculated indicate that only $2.7 \%$ of total gene diversity is due to diversity between the two populations. Genetic distance (Nei 1972) between the two populations is average to low for conspecific populations, with $D=0.001$ compared to $D=0.012$ previously estimated by Bigalke et al. (1993) between two springbok populations. By comparison, Grobler and Van der Bank (1994) recorded $D=0.0015-0.0088$ between conspecific impala Aepyceros melampus populations kept under different management regimes.

The average heterozygosity level calculated for the control population $(2 \%)$ is somewhat below levels of $H=4.1-5.1 \%$ previously estimated for springbok by Bigalke et al. (1993). This difference could be biologically significant, but is more likely due to the set of loci analysed during the current study not being identical to that previously sampled by Bigalke et al. (1993). Proportion of polymorphic loci is more in line with the range calculated by Bigalke et al. (1993), at $10.3 \%$ compared to 
Table 1. Polymorphic loci, allelic designations (reflecting relative mobilities), allelic frequencies and genetic variability values in the Chelmsford and Benfontein springbok populations. $p$-values under locus names and allelic frequencies indicate significance of allele frequency differences between populations and deviations from expected Hardy-Weinberg equilibrium of genotypes respectively.

\begin{tabular}{|c|c|c|c|}
\hline \multirow{2}{*}{ Locus } & \multirow{2}{*}{ Allele } & \multicolumn{2}{|c|}{ Population } \\
\hline & & Chelmsford & Benfontein \\
\hline Idh-2 & +120 & 0.446 & 0.280 \\
\hline$p<0.076$ & +100 & $\begin{array}{c}0.554 \\
p<0.197\end{array}$ & $\begin{array}{c}0.720 \\
p<0.907\end{array}$ \\
\hline$M p i-2$ & +118 & - & 0.063 \\
\hline \multirow[t]{2}{*}{$p<0.038$} & +100 & 1.00 & 0.896 \\
\hline & +86 & - & $\begin{array}{c}0.042 \\
p<0.324\end{array}$ \\
\hline$N p-1$ & +112 & 0.033 & 0.021 \\
\hline$p<0.694$ & +100 & $\begin{array}{c}0.967 \\
p<0.036\end{array}$ & $\begin{array}{c}0.979 \\
p<0.011\end{array}$ \\
\hline$P g m-2$ & +100 & 0.983 & 0.979 \\
\hline$p<0.873$ & +98 & $\begin{array}{c}0.017 \\
p<0.009\end{array}$ & $\begin{array}{c}0.021 \\
p<0.011\end{array}$ \\
\hline Prot-2 & +100 & 0.967 & 1.00 \\
\hline$p<0.203$ & +83 & $\begin{array}{c}0.033 \\
p<0.036\end{array}$ & - \\
\hline \multicolumn{2}{|c|}{ Average heterozygosity $(H)$} & $1.8( \pm 1.4) \%$ & $2.0( \pm 1.3) \%$ \\
\hline \multicolumn{2}{|c|}{ Proportion of polymorphic loci $(P)$} & $10.3 \%$ & $10.3 \%$ \\
\hline \multicolumn{2}{|c|}{ Average number of alleles per locus $(A)$} & 1.1 & 1.1 \\
\hline \multicolumn{2}{|c|}{ Mean $F$-statistic $\left(F_{S T}\right)$ across loci } & \multicolumn{2}{|c|}{0.027} \\
\hline
\end{tabular}

8.9-15.6\%. Significant similarities between results the two studies were found where corresponding loci are involved, which authenticate the results of the current study. For example, for the loci $I d h-2$ and $M p i-2$ virtually identical relative mobilities for alleles were recorded, with the same number of alleles and comparable allelic frequencies. This suggests that diversity levels in Benfontein is probably representative for springbok. What is more important is that (within the parameters of the present study) genetic diversity in the Chelmsford group effectively equals that in a numerically large population (Benfontein) which does not display the perceived abnormalities.

It therefore seems that there is not a serious inbreeding problem in the Chelmsford springbok population. Considering the comparatively large founder group $(n=49)$ and the relatively short period of isolation involved ( $<25$ years), this 
was to be expected. However, adequate heterozygosity in the Chelmsford population does not negate the possibility that the physical deformities may indeed have an alternative genetic basis. Species that have not undergone much inbreeding and artificial selection would have a higher frequency of recessive deleterious genes compared to domesticated forms (Slatis 1960). A malignant allele coding for the horn deformity included in the original founder population, could be present in a disproportional high frequency following several generations of isolation and interrupted gene flow. Such a mechanism was suggested by Foley and Atkinson (1984) as responsible for a high frequency of dental abnormalities among a population of Defassa waterbuck Kobus defassa. It is seems extraordinary that the springbok horn deformity should by chance occur only in females, and be on the same (left) side of the animals in almost all instances. This strengthens the argument for an alternate genetic basis for the distortions, and raises the possibility that a sex-linked gene or gene-complex may be involved.

\section{Skull morphology}

Tests for skewness and kurtosis of signed asymmetries of variables can reveal the existence of directional asymmetry (significantly skewed distribution) and antisymmetry (significantly negatively kurtotic or tailed-weighted distribution), which can confound differences in fluctuating asymmetry (FA). No variable distributions were significantly negatively kurtotic in either the Chelmsford or Benfontein populations (Table 2). Significant skewness was detected in bulla width (BULLAW) in both populations, and in mandible length and (MANDL) and

Table 2. Tests of normality (standardized skewness and kurtosis) of the distribution of mean differences between right and left sides of bilateral cranial and horn measurements $\left(\mathrm{X}_{\mathrm{R}}-\mathrm{X}_{\mathrm{L}}\right)$ in female springbok from Chelmsford Nature Reserve and Benfontein Game Farm. Significance of " $t$ " values indicated by: ${ }^{*}-p<0.05$ or ${ }^{* *}-p<0.01$ ). Horn length results are presented both including (HORNRW1) and excluding (HORNRW2) four individuals with obviously deformed horns.

\begin{tabular}{|c|c|c|c|c|c|c|}
\hline \multirow{2}{*}{ Variable } & \multicolumn{3}{|c|}{ Chelmsford } & \multicolumn{3}{|c|}{ Benfontein } \\
\hline & $n$ & Skewness & Kurtosis & $n$ & Skewness & Kurtosis \\
\hline MANDL & 17 & -0.907 & -0.426 & 27 & $-3.611^{* *}$ & $3.692^{* *}$ \\
\hline CONDPL & 19 & 0.098 & -1.052 & 36 & $2.741^{* *}$ & $2.676^{* *}$ \\
\hline MAIL & 18 & -0.301 & -0.533 & 37 & 0.342 & 0.071 \\
\hline MAXORB & 19 & 0.562 & 0.423 & 38 & -0.888 & 1.291 \\
\hline ORBIT & 19 & 0.066 & -0.615 & 38 & -1.344 & -0.991 \\
\hline BULLAW & 20 & $-2.119^{*}$ & $1.918^{*}$ & 36 & $2.786^{* *}$ & 1.556 \\
\hline OCCONW & 20 & -0.530 & 0.589 & 36 & $-1.930^{*}$ & $1.717^{*}$ \\
\hline HORNRW1 & 20 & -1.541 & $3.540 * *$ & 36 & 1.175 & $5.115^{* *}$ \\
\hline HORNRW2 & 16 & -0.634 & -0.476 & - & - & - \\
\hline HRNCIRC & 20 & 1.251 & 1.449 & 36 & 0.206 & 0.848 \\
\hline
\end{tabular}


occipito-premaxilla length (CONDPL) in Benfontein. Thus, comparisons of FA between populations in these variable may be confounded by the influence of directional asymmetry and should be treated with caution. However, Kolmogorov-Smirnov tests of normality were non-significant for all variables in both populations, with the sole exception of horn length in Chelmsford when deformed individuals were included (Table 3). It is also important to test for size-dependency of asymmetry results. Bivariate plots and correlation coefficients were obtained between VSS and the mean values $\left(\mathrm{X}_{\mathrm{R}}+\mathrm{X}_{\mathrm{L}}\right)$ of all variables. Significant correlation coefficients $(p<0.01)$ were obtained for OCCONW in both populations $(r=-0.569$ and -0.442 for Chelmsford and Benfontein respectively), and for BULLAW in

Table 3. Measures of fluctuating asymmetry (FA) of cranial and horn measurements in female springbok from Chelmsford Nature Reserve (CHM) and Benfontein Game Farm (BEN). Significance of Cothrane's (C) and Bartlett's (B) tests of homogeneity of variances, and the Kruskall-Wallis nonparametric test $(\mathrm{KW})$ is indicated by NS $-p>0.05,{ }^{*}-p<0.05,{ }^{* *}-p<0.01$. Sample sizes are indicated in parentheses. Horn length results are presented both including (HORNRW1) and excluding (HORNRW2) four individuals with obviously deformed horns.

\begin{tabular}{|c|c|c|c|c|c|c|c|c|c|c|c|}
\hline \multirow{3}{*}{ Variable } & \multicolumn{11}{|c|}{ Indices of fluctuating asymmetry (FA) } \\
\hline & \multicolumn{4}{|c|}{$\begin{array}{l}\text { Variance of signed } \\
\text { asymmetries (VSS) } \\
\operatorname{var}\left(\mathrm{X}_{\mathrm{R} .}-\mathrm{X}_{\mathrm{L}}\right) / n\end{array}$} & \multicolumn{2}{|c|}{$\begin{array}{c}\mathrm{VSS} / \text { size } \\
\operatorname{var}\left(\mathrm{X}_{\mathrm{R}}-\mathrm{X}_{\mathrm{L}}\right) / n / \\
\Sigma\left(\mathrm{X}_{\mathrm{R}}+\mathrm{X}_{\mathrm{L}}\right) / 2 n \\
\end{array}$} & \multicolumn{3}{|c|}{$\begin{array}{c}\text { Mean absolute deviation } \\
\text { (MAD) } \\
\Sigma\left|\mathrm{X}_{\mathrm{R}}-\mathrm{X}_{\mathrm{L}}\right| / n\end{array}$} & \multicolumn{2}{|c|}{$\begin{array}{c}\mathrm{MAD} / \text { size } \\
\Sigma\left|\mathrm{X}_{\mathrm{R}}-\mathrm{X}_{\mathrm{L}}\right| / n \mid \\
\Sigma\left(\mathrm{X}_{\mathrm{R} .}+\mathrm{X}_{\mathrm{L}}\right) / 2 n\end{array}$} \\
\hline & $\mathrm{CHM}$ & BEN & $\mathrm{C}$ & B & CHM & BEN & CHM & BEN & KW & $\mathrm{CHM}$ & BEN \\
\hline$\underset{(n)}{\text { MANDL }}$ & $\begin{array}{l}1.576 \\
(17)\end{array}$ & $\begin{array}{l}5.002 \\
(27)\end{array}$ & ** & * & $\begin{array}{c}0.009 \\
(17)\end{array}$ & $\begin{array}{c}0.027 \\
(27)\end{array}$ & $\begin{array}{c}1.018 \\
(17)\end{array}$ & $\begin{array}{c}1.549 \\
(27)\end{array}$ & NS & $\begin{array}{c}0.006 \\
(17)\end{array}$ & $\begin{array}{l}0.008 \\
(27)\end{array}$ \\
\hline $\begin{array}{c}\text { CONDPL } \\
(n)\end{array}$ & $\begin{array}{c}0.304 \\
(18)\end{array}$ & $\begin{array}{c}0.932 \\
(36)\end{array}$ & ** & * & $\begin{array}{c}0.002 \\
(18)\end{array}$ & $\begin{array}{c}0.004 \\
(36)\end{array}$ & $\begin{array}{c}0.468 \\
(18)\end{array}$ & $\begin{array}{c}0.692 \\
(36)\end{array}$ & NS & $\begin{array}{c}0.002 \\
(18)\end{array}$ & $\begin{array}{c}0.003 \\
(36)\end{array}$ \\
\hline $\begin{array}{l}\text { MAIL } \\
\qquad(n)\end{array}$ & $\begin{array}{c}0.777 \\
(18)\end{array}$ & $\begin{array}{c}1.418 \\
(37)\end{array}$ & NS & NS & $\begin{array}{c}0.011 \\
(18)\end{array}$ & $\begin{array}{c}0.020 \\
(37)\end{array}$ & $\begin{array}{c}0.728 \\
(18)\end{array}$ & $\begin{array}{c}0.929 \\
(37)\end{array}$ & NS & $\begin{array}{c}0.010 \\
(18)\end{array}$ & $\begin{array}{l}0.013 \\
(37)\end{array}$ \\
\hline$\underset{(n)}{\operatorname{MAXORB}}$ & $\begin{array}{c}0.379 \\
(19)\end{array}$ & $\begin{array}{c}0.879 \\
(38)\end{array}$ & * & NS & $\begin{array}{c}0.007 \\
(19)\end{array}$ & $\begin{array}{c}0.016 \\
(38)\end{array}$ & $\begin{array}{c}0.497 \\
(19)\end{array}$ & $\begin{array}{c}0.751 \\
(38)\end{array}$ & NS & $\begin{array}{c}0.009 \\
(19)\end{array}$ & $\begin{array}{l}0.014 \\
(38)\end{array}$ \\
\hline $\begin{array}{r}\text { ORBIT } \\
(n)\end{array}$ & $\begin{array}{c}0.256 \\
(19)\end{array}$ & $\begin{array}{c}1.003 \\
(38)\end{array}$ & $* *$ & ** & $\begin{array}{c}0.006 \\
(19)\end{array}$ & $\begin{array}{c}0.025 \\
(38)\end{array}$ & $\begin{array}{c}0.408 \\
(19)\end{array}$ & $\begin{array}{c}0.852 \\
(38)\end{array}$ & $* *$ & $\begin{array}{c}0.010 \\
(19)\end{array}$ & $\begin{array}{c}0.021 \\
(38)\end{array}$ \\
\hline $\begin{array}{l}\text { BULLAW } \\
(n)\end{array}$ & $\begin{array}{c}0.576 \\
(20)\end{array}$ & $\begin{array}{c}1.352 \\
(36)\end{array}$ & * & * & $\begin{array}{c}0.029 \\
(20)\end{array}$ & $\begin{array}{c}0.063 \\
(36)\end{array}$ & $\begin{array}{c}0.838 \\
(20)\end{array}$ & $\begin{array}{c}0.816 \\
(36)\end{array}$ & NS & $\begin{array}{c}0.043 \\
(20)\end{array}$ & $\begin{array}{l}0.038 \\
(36)\end{array}$ \\
\hline $\begin{array}{c}\text { OCCONW } \\
(n)\end{array}$ & $\begin{array}{c}0.532 \\
(20)\end{array}$ & $\begin{array}{c}0.513 \\
(36)\end{array}$ & NS & NS & $\begin{array}{c}0.045 \\
(20)\end{array}$ & $\begin{array}{c}0.046 \\
(36)\end{array}$ & $\begin{array}{c}0.548 \\
(20)\end{array}$ & $\begin{array}{c}0.577 \\
(36)\end{array}$ & NS & $\begin{array}{c}0.047 \\
(20)\end{array}$ & $\begin{array}{c}0.052 \\
(36)\end{array}$ \\
\hline $\begin{array}{c}\text { HORNW } 1 \\
(n)\end{array}$ & $\begin{array}{c}875.6 \\
(20)\end{array}$ & $\begin{array}{r}66.43 \\
(36)\end{array}$ & $* *$ & $* *$ & $\begin{array}{c}6.251 \\
(20)\end{array}$ & $\begin{array}{c}0.389 \\
(36)\end{array}$ & $\begin{array}{r}14.55 \\
(20)\end{array}$ & $\begin{array}{r}5.48 \\
(36)\end{array}$ & NS & $\begin{array}{c}0.104 \\
(20)\end{array}$ & $\begin{array}{c}0.032 \\
(36)\end{array}$ \\
\hline $\begin{array}{c}\text { HORNW } 2 \\
(n)\end{array}$ & $\begin{array}{c}9.362 \\
(15)\end{array}$ & $\begin{array}{r}66.43 \\
(36)\end{array}$ & $* *$ & $* *$ & $\begin{array}{c}0.061 \\
(15)\end{array}$ & $\begin{array}{c}0.389 \\
(36)\end{array}$ & $\begin{array}{c}2.43 \\
(15)\end{array}$ & $\begin{array}{c}5.48 \\
(36)\end{array}$ & NS & $\begin{array}{l}0.016 \\
(15)\end{array}$ & $\begin{array}{c}0.032 \\
(36)\end{array}$ \\
\hline $\begin{array}{c}\text { HRNCIRC } \\
(n)\end{array}$ & $\begin{array}{l}1.208 \\
(20)\end{array}$ & $\begin{array}{c}2.123 \\
(36)\end{array}$ & NS & NS & $\begin{array}{c}0.021 \\
(20)\end{array}$ & $\begin{array}{c}0.033 \\
(36)\end{array}$ & $\begin{array}{c}0.75 \\
(20)\end{array}$ & $\begin{array}{r}1.18 \\
(36)\end{array}$ & * & $\begin{array}{l}0.013 \\
(20)\end{array}$ & $\begin{array}{c}0.018 \\
(36)\end{array}$ \\
\hline
\end{tabular}


Benfontein $(r=-0.504)$. Interpretation of FA population differences in these variables should be treated with caution.

Our hypothesis assumed that if the high incidence of horn abnormalities is a result of inbreeding depression, then this population should show: (1) increased levels of fluctuating asymmetry; and (2) decreased body size, compared with the larger and presumably outcrossed population from Benfontein $(n=5000)$. The former prediction is contradicted by the results in Table 3 in that FA is almost always higher in Benfontein than in Chelmsford, significantly so for six variables when tested by means of Cochrane's tests for index 4 (VSS) of Palmer and Strobeck (1986). It is notable that, although the VSS was extremely high for horn length (HORNRW1 ) in Chelmsford when individuals with deformities were included, this value was considerably less than for Benfontein (9.362 as opposed to 66.43) when obviously deformed individuals were excluded from the Chelmsford sample. This suggests a surprisingly high level of FA in horn length in the supposedly outcrossed Benfontein sample.

As far as the second prediction (decreased body size) is concerned, Chelmsford animals are smaller than Benfontein animals in all variables except premaxilla length (MAIL) and occipital condyle width (OCCONW), significantly $(p<0.05)$ so in four variables (MANDL, BULLAW, HORNRW, HRNCIRC) (Table 4). Differences in horn measurements appear more pronounced (higher $t$-values) than cranial differences.

It is clear that springbok from Chelmsford do not display pronounced fluctuating asymmetry (FA) in either cranial or horn bilateral measurements, with the obvious exception of horn length, when deformed individuals are included.

Table 4. Summary statistics of cranial and horn measurements of female springbok from Chelmsford Nature Reserve and Benfontein Game Farm, and $t$-tests of significance of mean differences (NS non-significant, ${ }^{*}-p<0.05,{ }^{* *}-p<0.01$ ). Horn length (HORNRW) results are presented for a sample excluding four individuals with obviously deformed horns and an additional individual with under-sized horns.

\begin{tabular}{|c|c|c|c|c|c|c|c|c|}
\hline \multirow{2}{*}{ Variable } & \multicolumn{3}{|c|}{ Chelmsford } & \multicolumn{3}{|c|}{ Benfontein } & \multirow{2}{*}{$t$} & \multirow{2}{*}{$p$} \\
\hline & $n$ & Mean & SD & $n$ & Mean & $\mathrm{SD}$ & & \\
\hline MANDL & 17 & 181.98 & 5.63 & 27 & 185.88 & 5.95 & -2.16 & * \\
\hline CONDPL & 18 & 204.83 & 5.07 & 36 & 206.89 & 6.17 & -1.22 & NS \\
\hline MAIL & 19 & 71.30 & 4.51 & 37 & 70.96 & 4.52 & 0.26 & NS \\
\hline MAXORB & 19 & 52.57 & 2.36 & 38 & 53.91 & 2.72 & -1.83 & NS \\
\hline ORBIT & 19 & 39.88 & 1.29 & 38 & 39.95 & 1.17 & -0.19 & NS \\
\hline BULLAW & 20 & 19.62 & 1.80 & 36 & 21.31 & 2.38 & -2.76 & ** \\
\hline OCCONW & 20 & 11.69 & 1.28 & 36 & 11.03 & 0.99 & 2.16 & $*$ \\
\hline HORNRW & 15 & 153.17 & 18.80 & 36 & 170.91 & 20.97 & 2.83 & $* *$ \\
\hline HRNCIRC & 20 & 56.48 & 5.92 & 36 & 64.85 & 5.31 & -5.43 & ** \\
\hline
\end{tabular}


Chelmsford animals are significantly smaller in certain horn and cranial measurements than Benfontein animals. The latter finding, but not the former, is consistent with the hypothesis of inbreeding depression in the Chelmsford population. However, regarding the level of FA, the study by Lacy and Horner (1996) on captive Rattus villosissimus is most revealing. These authors found that deliberate inbreeding over several generations resulted in moderate increases in FA, but a more discernible increase in the prevalence of gross morphological abnormalities (such as supernumerary incisors and malformed digits), which led them to propose that inbreeding depression may act in a threshold manner on morphology. The relatively high prevalence of females having deformed horns in the Chelmsford population may therefore be symptomatic of some degree of inbreeding depression, despite being unaccompanied by increased FA levels.

\section{Genetic versus environmental determinants for abnormalities}

The question whether the development of phenotypic characters reflects mainly environmental influences or is largely determined by genetic background is still under discussion (Hartl et al. 1991). Enzyme heterozygosity is frequently considered to be associated with enhanced capacity of metabolism (Hartl et al. 1991), which would give inbred animals smaller body size. Yet, based on our genetic analysis, the Chelmsford animals are apparently not inbred. Consequently, the

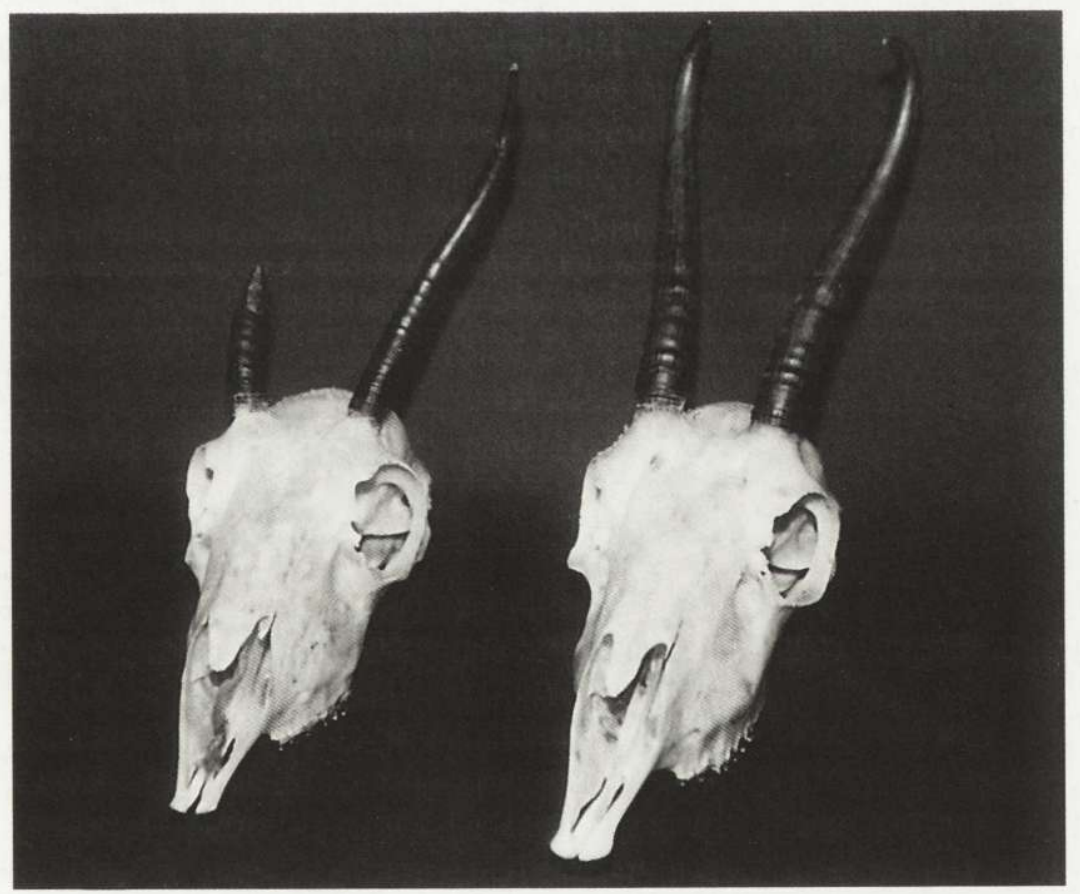

Fig. 1. Normal and deformed horns from 2 springbok females collected from the Chelmsford Nature Reserve. 
smaller body size, considered together with the horn deformities, could point to an environmental influence. Many environmental factors undoubtedly influence growth rate (Røed 1987). Chelmsford Nature Reserve is far outside the (current) natural distribution area of springbok as given in widely used references (eg Smithers 1983). Environmental conditions such as temperature and nutrient availability may therefore be sub-optimal for springbok, which could explain the reduced body size of Chelmsford animals and possibly the horn deformities as well (Fig. 1). Weights and body size are important determinants of fitness and can influence the birth weight and future survival of young (Røed 1987). Environmentally induced smaller body size could thus be linked to the perceived decreased reproductive performance in Chelmsford springbok. An argument against this is that the current exclusion of Chelmsford from the distribution area of springbok may not be historically correct (A. E. Bowland, pers. comm.). Nevertheless, the Chelmsford founder stock may have been genetically adapted to the different environmental conditions of the historically recent distribution area, leading to developmental deficiencies at Chelmsford when the genotype was exceeded by the environmental conditions experienced.

\section{Conclusion}

The springbok from Chelmsford Nature Reserve do not display pronounced fluctuating asymmetry or loss of genetic diversity. They are however smaller than animals collected from the control group, which can probably be attributed to environmental influences. The horn deformities occurring in the population may also have an environmental base, but consistencies in the deformities (almost always the left horn of females is affected) suggests that a genetic mechanism, possibly a sex-linked mutation with no other discernible phenotypic effects, may be involved.

Acknowledgement: The authors would like to express their gratitude to Dr Anthony Bowland of the Natal Parks Board who initiated this study, De Beers Consolidated, and to personnel of the Chelmsford Nature Reserve and Benfontein Game farm for assistance during sample collection.

\section{References}

Bigalke R. C. and Van Hensbergen H. J. 1992. Observations on a reproductively isolated population of blesbok (Damaliscus dorcas phillipsi) in a mineral deficient environment. [In: Ongulés/Ungulates 91. F. Spitz, G. Janeau, G. Gonzalez and S. Aulagnier, eds]. Societe Francaise pour l'Etude et ala Protection des Mammiferes - Institut de Recherche sur les Gramd Mammiferes, Paris: 497-503.

Bigalke R. C., Hartl G. B., Berry M. P. S. and Van Hensbergen H. J. 1993. Population genetics of the springbok Antidorcas marsupialis - a preliminary study. [In: Ecological genetics in mammals. G . B. Hartl and J. Markowski, eds]. Acta Theriologica 38, Suppl. 2: 103-111.

Borkowska A. and Ratkiewicz M. 1996. Relationship between allozyme heterozygosity and gut morphology in Apodemus agrarius. Acta Theriologica 41: 367-374.

De Blase A. F. and Martin R. E. 1981. A manual of mammalogy. With keys to families of the world. William C. Brown Company Publishers, Dubuque, Iowa: 1-436. 
Foley R. A. and Atkinson S. 1984. A dental abnormality among a population of Defassa waterbuck (Kobus defassa Ruppell 1835). African Journal of Ecology 22: 289-294.

Grobler J. P. and Van der Bank F. H. 1994. Isozyme variation in South African impala (Aepyceros melampus) populations under different management regimes. South African Journal of Wildlife Research 24B: 89-94.

Harris H. and Hopkinson D. A. 1976. Handbook of enzyme electrophoresis in human genetics. North-Holland, Amsterdam: 1-318.

Hartl G. B., Lang G., Klein F. and Willing R. 1991. Relationships between allozymes, heterozygosity and morphological characters in red deer (Cervus elaphus), and the influence of selective hunting on allele frequency distributions. Heredity 66: 343-350.

Lacy R. C. 1992. The effects of inbreeding on isolated populations: are minimum viable population sizes predictable. [In: Conservation biology. The theory and practice of nature conservation, preservation and management. P. L. Fiedler and S. K. Jain, eds]. Chapman and Hall, New York \& London: 278-296.

Lacy R. C. and Horner B. E. 1996. Effects of inbreeding on skeletal development of Rattus villosissimus. Journal of Heredity 87: 277-287.

Murphy R. W., Sites J. W., Buth D. G. and Haufler C. H. 1990. Proteins I: isozyme electrophoresis. [In: Molecular systematics. D. M. Hillis and C. Morris, eds]. Sinauer Associates, Massachusetts: 45-126.

Nei M. 1972. Genetic distances between populations. The American Naturalist 106: 282-292.

Nei M. 1975. Molecular population genetics and evolution. North-Holland, Amsterdam: 1-288.

Palmer A. R and Strobeck C. 1986. Fluctuating asymmetry: measurement, analysis, patterns. Annual Review of Ecology and Systematics 17: 391-421.

Patterson B. D. and Patton J. L. 1990. Fluctuating asymmetry and allozymic heterozygosity among natural populations of the pocket gophers Thomomys bottae. Biological Journal of the Linnaean Society 40: 21-36.

Rautenbach I. L. 1971. Ageing criteria in the springbok, Antidorcus marsupialis, (Zimmerman, 1780) (Artiodactyla: Bovidae). Annals of the Transvaal Museum 27: 83-133.

Robinson T. J., Op't Hof J. and Geerthsen J. M. P. 1978. Polymorphic genetic markers in the springbok Antidorcas marsupialis (Bovidae). South African Journal of Science 74: 184-186.

Røed K. H. 1987. Transferrin variation and body size in reindeer, Rangifer tarandus L. Hereditas 106: $67-71$.

Scribner K. T., Smith M. H. and Johns P. E. 1989. Environmental and genetic components of antler growth in white-tailed deer. Journal of Mammalogy 70: 284-291.

Skinner J. D. and Smithers R. H. N. 1990. The mammals of the southern African subregion. University of Pretoria, Pretoria: 1-771.

Slatis H. M. 1960. An analysis of inbreeding in the European bison. Genetics 45: 275-287.

Smith M. H., Chesser R. K., Cothran E. G. and Johns P. E. 1983. Genetic variability and antler growth in a natural population of white-tailed deer. [In: Antler development in Cervidae. R. Brown, ed]. Ceasar Kleberg Foundation, Kingsville: 365-387

Smithers R. H. N. 1983. The mammals of the Southern African Subregion. University of Pretoria, Pretoria: $1-736$.

Soulé M. 1978. Heterozygosity and developmental stability: another look. Evolution 33: 396-401.

Vrba E. S., Vaisnys J. R., Gatesby J. E., De Salle R. and Wei K. Y. 1994. Analysis of paedomorphosis using allometric characters: the example of Reduncini antelopes (Bovidae, Mammalia). Systematic Biology 43: 92-116.

Watt W. B. 1985. Bioenergetics and evolutionary genetics: opportunities for new synthesis. The American Naturalist 125: 118-143.

Wright S. 1965. The interpretation of population structure by $F$-statistics with special regard to systems of mating. Evolution 19: 395-420.

Received 28 November 1997, accepted 12 November 1998. 